\title{
LINEAR ALKALI CORRELATION IN OCEANIC ALKALI BASALTS
}

\author{
H. S. YODER, JR., and F. CHAYES
}

\begin{abstract}
YODER, H. S., JR., and CHAYES, F., 1986: Linear alkali correlation in oceanic alkali basalts. Bull. Geol. Soc. Finland 58, Part 1, 81-94.

A strong positive correlation was found between $\mathrm{Na}_{2} \mathrm{O}$ and $\mathrm{K}_{2} \mathrm{O}$ in basic alkali rocks from the Hawaiian Islands and Canary Islands. The correlated variance of the variables in each province is $79 \%$ and $76 \%$, respectively. Six possible explanations were examined. (1) Buffer control by phases such as a sodium-bearing clinopyroxene and a mica or a single phase such as an amphibole is possible, but each buffer has limitations. (2) The phase-equilibrium relations at high pressures may also constrain the alkali ratio in these rocks, but the relevant complex system has not as yet been investigated. (3) Metasomatism, resulting in the addition or subtraction of materials, is not considered appropriate because of the high concentration of $\mathrm{K}$ relative to $\mathrm{Na}$ at high temperatures in the fluid phase. (4) The behavior of $\mathrm{Na}$ and $\mathrm{K}$ as incompatible trace elements may result in a fixed ratio of alkalies in magmas produced from batch melting. (5) Mixing of a fractionally derived early magma with subsequent magmas, formed either at the same invariant point or from an independent source, may generate a series of mixed magmas with a linear relationship between incompatible elements. (6) The positive correlation of alkalies may result from the new closure (that is, the new set of means and variances characteristic of any set of extracts) attending separation of magma from its parent. No satisfactory explanation of the strong alkali correlation has been obtained. The feature, resulting from one or several mechanisms, may be common to other oceanic island rock series as well as to some calcalkaline sequences.
\end{abstract}

Key words: alkali correlation, Oceanic alkali basalts, Hawaiian Islands, Canary Islands.

H. S. Yoder, Jr., and F. Chayes: Geophysical Laboratory, Carnegie Institution of Washington, Washington D.C., 20008, USA.

\section{Introduction}

Various investigators have advanced a wide variety of mechanisms by which alkali-rich basalts may be generated (Table 1). Because of the apparent necessity of deriving a liquid enriched in alkalies from a presumably alkalipoor source, e.g., garnet peridotite, the mechanisms commonly involve addition of alkali-rich material to, or extraction of alkali-poor material from, the source prior to melting. The derivation of alkali basalt magma from alkali-enriched sources has recently been revived on the basis of traceelement and isotopic data. Whatever the mechanism, it should operate world wide and provide sufficient volumes of liquid to account for the alkali-rich floods of the Hebridean province, Canary Islands, Saudi Arabia, and Syria, for examples.

In spite of the considerable overlap in alkali 
Table 1. Mechanisms proposed by various authors for production of alkali-rich magma.

Source Requirement

Alkali-rich source

Metasomatized parent

\section{Source Modification}

Metasomatic enrichment

Biotite or amphibole decomposition

Volatile transfer

High $\mathrm{H}_{2} \mathrm{O}$ pressure

High $\mathrm{CO}_{2}$ pressure

\section{Magma Modification}

Assimilation

Biotite or amphibole resorption

Desilication

Phase separation

Orthopyroxene extraction

Hematite extraction

Immiscible liquid separation

Physicochemical Processes

Invariant point melting

Incongruent melting

Zone refining

Fractionation

Fractional melting

Liquid fractionation (diffusion)

of eclogite

at high pressure

\section{Mechanical Processes}

Filter pressing

Tectonic control
Becke (1903), Barth (1936)

von Eckermann (1948)

von Eckermann (1942), Gummer and Burr (1943), Tilley (1952)

Goldschmidt (1922), Bowen (1928), Holmes and

Harwood (1937)

Smyth (1913, 1927), Bailey $(1966,1970)$

Bultitude and Green (1968)

Eggler (1974), Bailey (1974), Brey and Green (1975), Mysen and Boettcher (1975)

Daly (1910), Shand (1922), Tilley and Harwood (1931)

Bowen (1928)

Shand (1922)

Holmes and Harwood (1932), Powers (1935), Larsen (1940)

Bailey and Schairer (1966)

Marshall (1914), Holgate (1954)

Schairer and Yoder (1964), Yoder (1978)

Bowen (1928), Tilley (1958)

Harris (1957)

Waters (1955)

Hamilton (1965), Kogarko et al. (1974)

O'Hara and Yoder (1967)

Yoder and Tilley (1961), Kushiro and Kuno (1963), Kushiro (1968)

Harker (1909), Bowen (1915)

Harker (1912), Geijer (1922) content of alkali basalt and tholeiites, a distinction was made between the two magma types by Macdonald and Katsura (1964; see also Macdonald 1968) on the basis of »positive microscopic evidence.» They cited $\gg$ the presence of titanian augite, of true groundmass olivine, and of interstitial alkali feldspar» as characteristic of alkali basalt. They applied these criteria to the rocks of Hawaii, and drew a definitive line between the rock types in a $\left(\mathrm{K}_{2} \mathrm{O}+\mathrm{Na}_{2} \mathrm{O}\right)$ vs. $\mathrm{SiO}_{2}$ plot (Fig. 1). Even though the line may vary in position from petrographic province to province, the alkali basalts tend to be richer than tholeiites in alkalies for a given silica content. On the other hand, there are representatives of each basalt type having the same alkali content. It is to be noted that on the original Macdonald-Katsura diagram compositions plotting in the vicinity of the proposed boundary for Hawaiian rocks are less abundant than those more distant from it. And, with increasing $\mathrm{SiO}_{2}$, each basalt type appears to diverge in composition from the dividing line, beginning at a central composition near $A$ of Fig. 1. Although one might wish to jump to the conclusion that such a central composition defines the common source, it should be recalled 


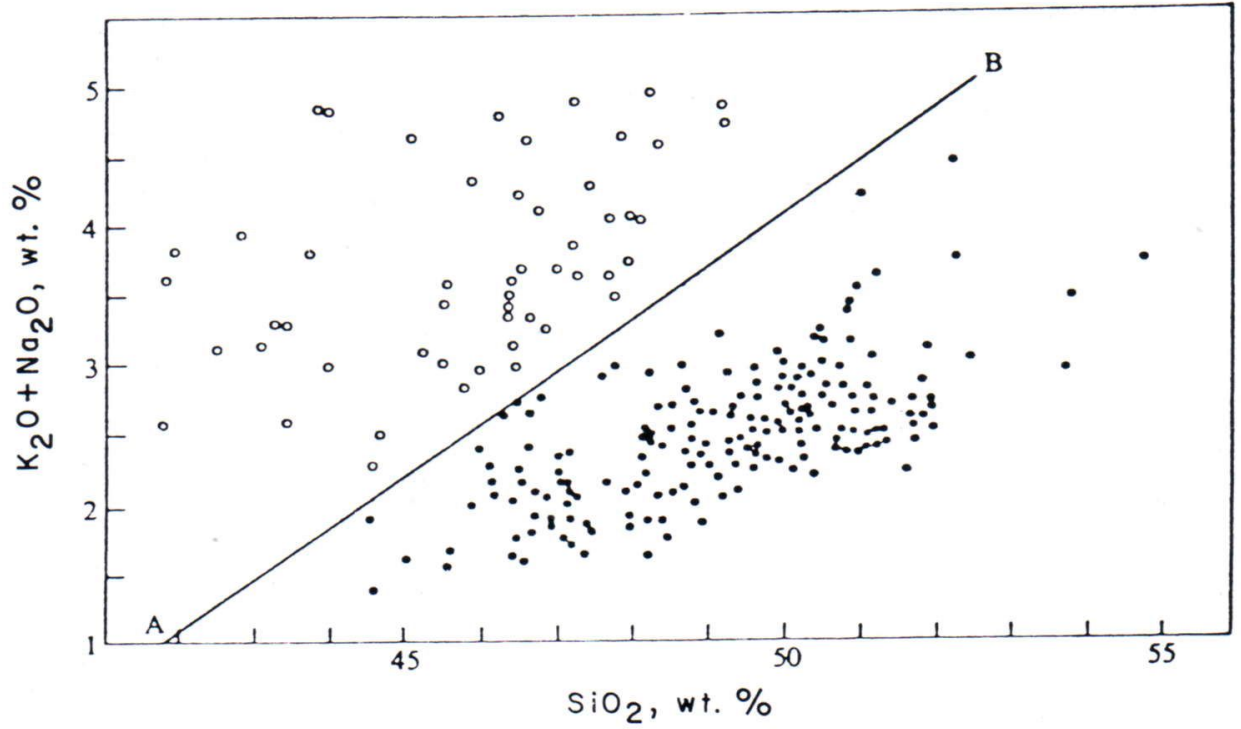

Fig. 1. Alkali vs. silica for Hawaiian basaltic rocks (Macdonald and Katsura 1964). Line $A-B$ divides alkalic rocks (above $A-B$ ) and tholeiites (below $A-B$ ) on the basis of mineralogical criteria.

that each magma type may be generated at different pressures and subtle differences in physicochemical relations may have been attained at the time of magma separation.

The Macdonald-Katsura dividing line contains compositions that are subparallel with the plane of critical undersaturation as defined by Yoder and Tilley (1962). That is, the join Fo-Ab in the $\mathrm{K}$-free model system used by Yoder and Tilley, which separates in principle the nepheline-normative rocks from the tholeiitic or subalkaline rocks, is close to and almost parallels the MacdonaldKatsura dividing line ( $c f$. DeLong and Hoffman 1975). Because of solid solutions, especially those in the clinopyroxene, and possibly oxidation state of iron, many alkali basalts are "transitional» and have a small amount of hypersthene in the norm. In fact, more than half of the original Hawaiian Island alkalic basic rocks described by Macdonald and Katsura lack normative nepheline, and this is also true for $41 \%$ of 221 Hawaiian basaltic rocks in RKOC76 (Chayes et al., 1977) that plot above their dividing line. Nevertheless, the nepheline-normative character of alkaline rocks is a useful concept in regard to the interpretation of phase equilibria, and has recently been proposed by the IUGS Subcommission on Systematics and Igneous Petrology as a diagnostic feature of major importance. Conversely, other solid solutions result in the absence of modal nepheline (or analcime, alkali-rich glass) until considerable normative nepheline $(>7 \%)$ is present in an alkaline basalt. For this latter reason, basanite, a term now frequently applied to rocks by definition requiring but in fact often lacking modal nepheline, has been included in the data reductions used here.

The close proximity of the critical plane of undersaturation, determined from a consideration of phases high in $\mathrm{Na}_{2} \mathrm{O}$ (i.e., albite, nepheline), to the Macdonald-Katsura dividing line in which $\mathrm{Na}_{2} \mathrm{O}$ and $\mathrm{K}_{2} \mathrm{O}$ are treated together, as apparently first proposed by Iddings (1898), implies an unusual role for $\mathrm{K}_{2} \mathrm{O}$. Either $\mathrm{K}$ is indeed a proxy for $\mathrm{Na}$ or its thermochemical properties are at least similar to those of $\mathrm{Na}$. It was this relationship that motivated the authors initially to examine the relations between alkalies. 


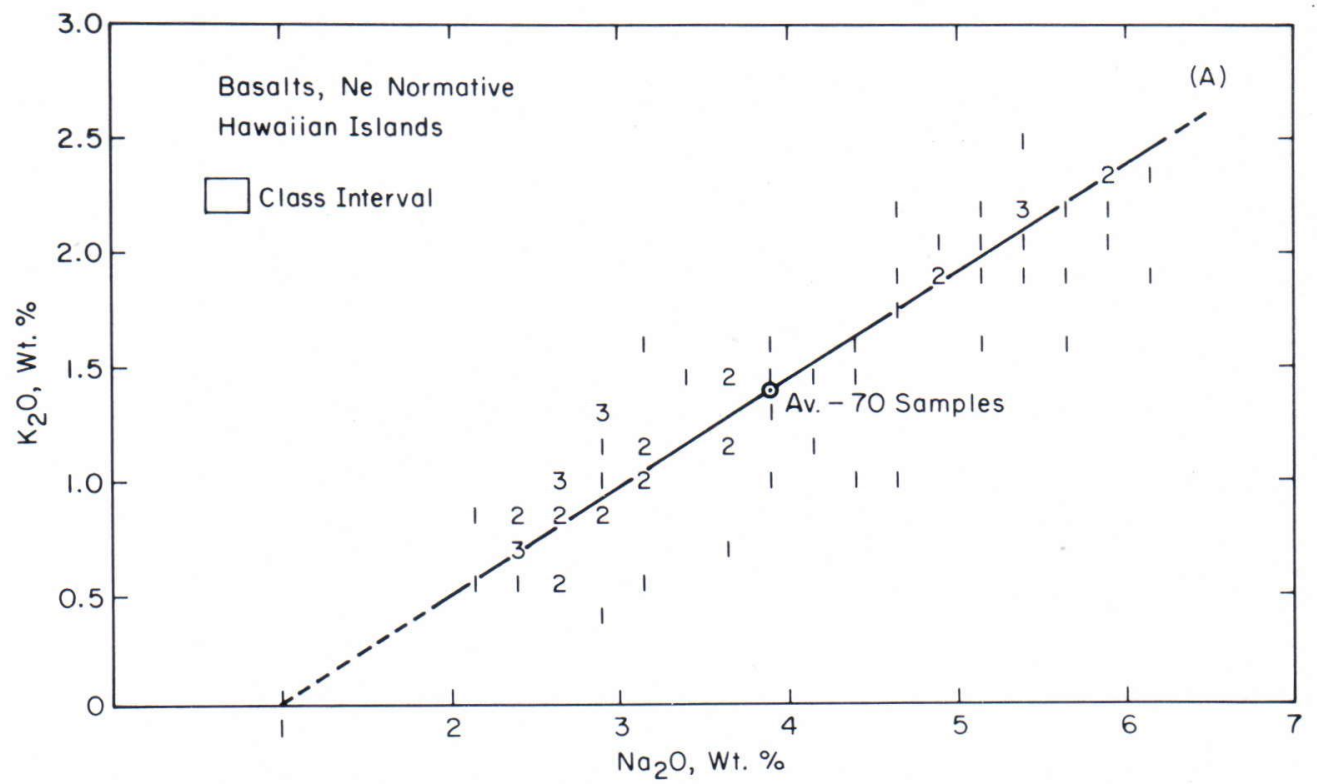

Fig. 2A. Plot of $\mathrm{K}_{2} \mathrm{O}$ vs. $\mathrm{Na}_{2} \mathrm{O}$ for Ne-normative basalts from the Hawaiian Islands. Line is reduced major-axis regression. Numbers indicate sample frequency in class interval illustrated $\left(0.15 \mathrm{~K}_{2} \mathrm{O}\right.$ and $0.25 \mathrm{Na}_{2} \mathrm{O}$ wt. $\left.\%\right) . r=0.891$.

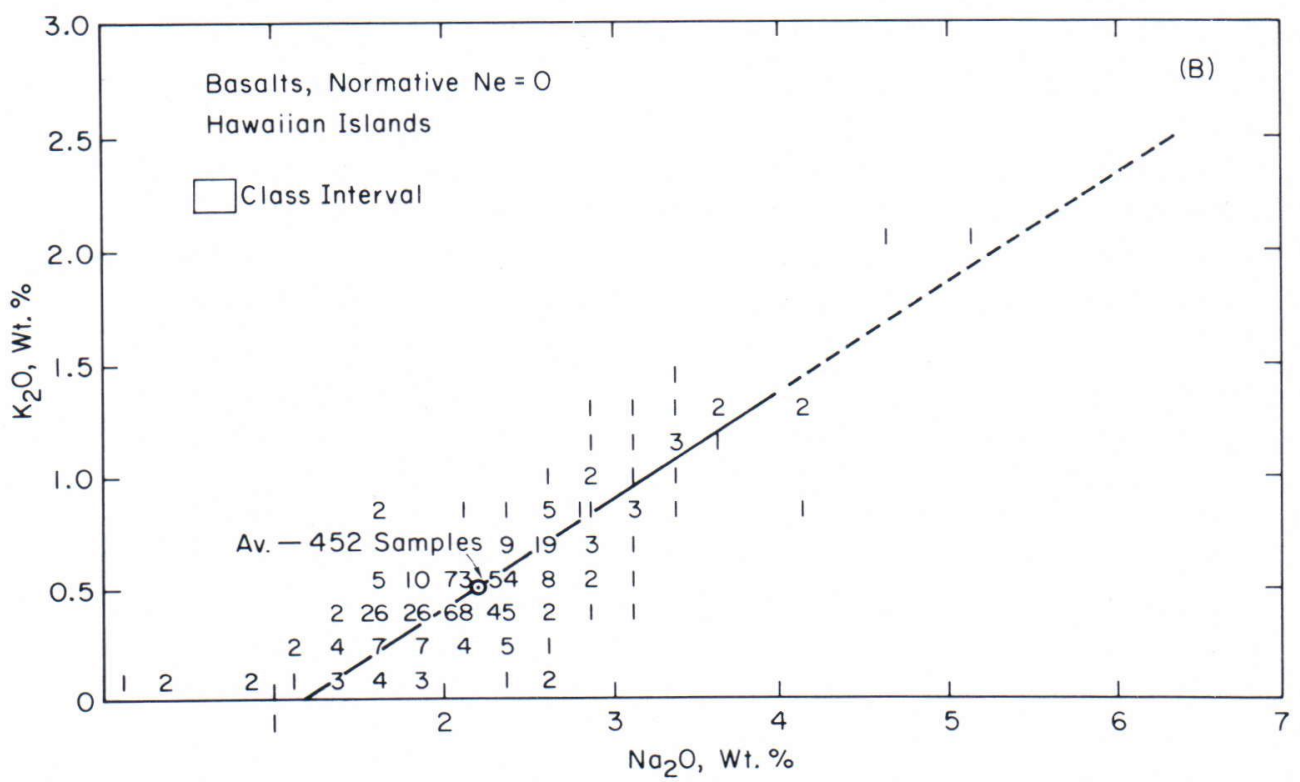

Fig. 2B. Plot of $\mathrm{K}_{2} \mathrm{O} v s$. $\mathrm{Na}_{2} \mathrm{O}$ for Hy-normative basalts from the Hawaiian Islands. $r=0.792$. 


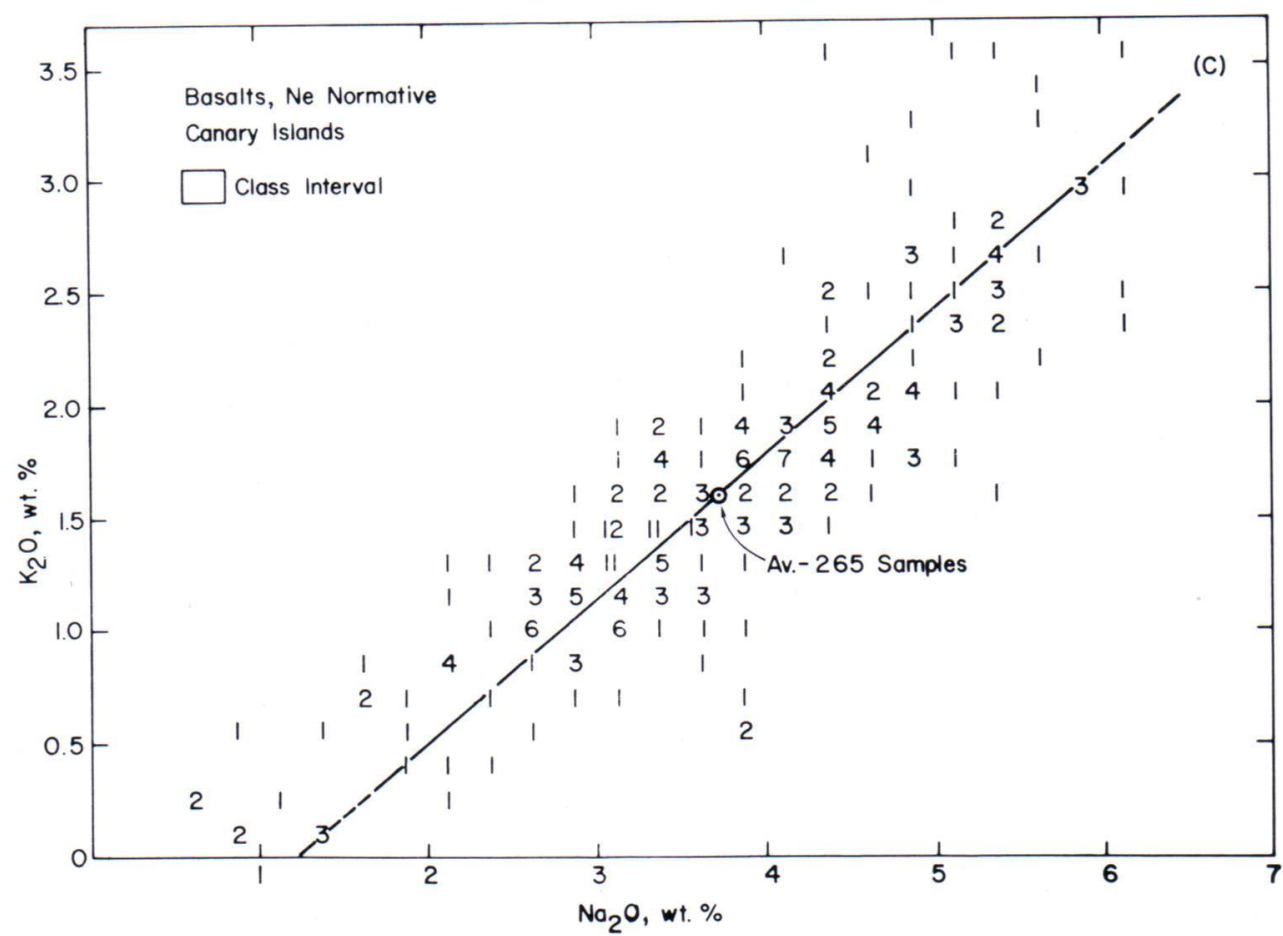

Fig. 3. Plot of $\mathrm{K}_{2} \mathrm{O}$ vs. $\mathrm{Na}_{2} \mathrm{O}$ for Ne-normative basalts from Canary Islands. See Fig. 2 for explanation. $r=0.874$.

\section{Statistical analysis}

The study is confined to two areas in the world for which the greatest numbers of chemical analyses per unit area of igneous rocks are available, the Hawaiian Islands and the Canary Islands. The data bank used in the statistical analysis of the chemical analyses is RKOC76; acceptable chemical analyses were limited to those with $\mathrm{SiO}_{2}>42, \mathrm{H}_{2} \mathrm{O}<1$, and $\mathrm{Na}_{2} \mathrm{O}<6.5$ wt. $\%$. The data bank contains 70 such $\mathrm{Ne}$ normative analyses from the Hawaiian Islands and 265 from the Canary Islands. In addition, 452 analyses lacking normative $\mathrm{Ne}$ were retrieved from the Hawaiian Island file. Plots of $\mathrm{K}_{2} \mathrm{O} v s$. $\mathrm{Na}_{2} \mathrm{O}$ for these sets of chemical analyses are given in Figs. 2A, 3, and 2B, respectively. The frequency of occurrence of samples within classes $0.15 \mathrm{~K}_{2} \mathrm{O}$ and $0.25 \mathrm{Na}_{2} \mathrm{O}$ wt. $\%$ wide is dis- played for each data set. The reduced major axis line

$$
Y-\bar{y}=\frac{\sigma_{\mathrm{y}}}{\sigma_{\mathrm{x}}}(X-\bar{x}),
$$

where $Y$ is $\mathrm{K}_{2} \mathrm{O}, X$ is $\mathrm{Na}_{2} \mathrm{O}$, and $\sigma$ is the standard deviation, is also shown in the diagrams. (The reduced major axis line is used because it describes interdependence without designation of the dependent and independent variables. There is no basis in the present petrological application for making the designation.)

The correlation of $\mathrm{Na}_{2} \mathrm{O}$ with $\mathrm{K}_{2} \mathrm{O}$ for the data set of Hawaiian nepheline normative rocks is 0.891 , that is, the correlated variance of the variables is $79 \%$, whereas for alkalies in the tholeiitic rocks, it is close to $63 \%$. For the nepheline normative rocks of the Canary Islands, $76 \%$ of the variance of either variable may be described as a linear function of the other. (There 
are too few tholeiitic rocks in the Canary Islands for statistical analysis.) The near coincidence of the regression lines for the Hawaiian rocks is noteworthy. On the other hand, the slope of the regression line for the Canary Island rocks is quite different from that of the Hawaiian petrographic province. For all three regression lines the intercept is about $1 \% \mathrm{Na}_{2} \mathrm{O}$, a possibly fictive feature with puzzling implications that will be discussed below.

\section{Discussion}

The substantial positive linear correlation between alkalies in both alkaline and tholeiitic rocks from the most frequently analyzed regions in the world raises a fundamental question. How can the slope of $\mathrm{K}_{2} \mathrm{O}$ vs. $\mathrm{Na}_{2} \mathrm{O}$ remain relatively constant through the generation process, or the fractionation process, or both? The early appearance of plagioclase (Yoder and Tilley 1962, Tilley et al. 1965, Tilley and Thompson 1972) in a relatively low-pressure fractionation process, for example, would preclude a constant relationship of the alkalies. Six possible explanations are examined to account for this relationship.

\section{Buffer control}

On the assumption that these rocks are the partial melting product of a parental material such as garnet peridotite, the $\mathrm{Na}_{2} \mathrm{O}$ might be buffered by the jadeite component of the clinopyroxene, and to a minor extent by the $\mathrm{Na}$ content of pyropic garnet. The $\mathrm{K}_{2} \mathrm{O}$ component, however, does not have an obvious buffer, even though one omphacite inclusion in diamond was found to contain $1 \% \mathrm{~K}_{2} \mathrm{O}$ (Hall and Smith 1984) - most pyroxenes from nodules contain trace amounts of $\mathrm{K}_{2} \mathrm{O}$. (The $\mathrm{K}$ in such pyroxenes may be assigned to a potassic acmite, $\mathrm{KFe}^{3+} \mathrm{Si}_{2} \mathrm{O}_{6}$, or a potassic titanaugite, $\mathrm{KMg}_{0.5}$ $\mathrm{Ti}_{0.5} \mathrm{Si}_{2} \mathrm{O}_{6}$, end member.) There are several additional potential candidates. Sanidine is stable at high pressures and is presumed to be primary in eclogite nodules found in some kimberlite pipes (Nixon 1960). Its absence as a primary phase in other nodules is probably due to the reaction

$$
\mathrm{Sa}+2 \mathrm{Fo} \rightarrow \mathrm{Ks}+4 \mathrm{En}
$$

at pressures less than those of the geotherm (Wendlandt and Eggler 1980b, p. 450, Fig. 10). The product kalsilite (Ks) would probably be held in solid solution in nepheline. Nepheline is believed to coexist with enstatite (En) metastably at $1 \mathrm{~atm}$ (Yoder 1952, p. 586; Schairer and Yoder 1961, p. 143; Chinner and Schairer 1962) and at 9 kbar (Yoder 1964), and stably from 11 to 24 kbar (Kushiro 1965); however, these latter findings were not confirmed (Windom and Boettcher 1981). Hypersthene is found in nodules in nepheline-bearing basalts, but the stable coexistence of hypersthene and nepheline at the high pressures where the nodules and basaltic liquid are presumed to have originated has yet to be demonstrated.

The high-pressure, hydrated form of sanidine, $\mathrm{KAlSi}_{3} \mathrm{O}_{8} \cdot \mathrm{H}_{2} \mathrm{O}$, synthesized by Seki and Kennedy (1964) has not been observed in nodules.

Phlogopite could also serve as a buffer, but the small proportions compatible with the modes of nodules and heat-production constraints would probably be consumed in the initial melt. Possible phlogopite buffering relations are outlined schematically in a diagram (Fig. 4) deduced in part from Luth (1967) and Modreski and Boettcher (1973). Compositions representative of part of the parental material lie in the phase triangle $\mathrm{Fo}+\mathrm{En}+\mathrm{Phlog}$, an assemblage that begins to melt at point $P$. The composition marked with a star, for example, which contains $10 \%$ Phlog, would yield only $6 \%$ liquid under equilibrium conditions before phlogopite would be consumed. A diagram of similar topology would probably be valid also for a potassic amphibole, e.g., kaersutite, stable at pressures less than about 35 kbar.

Dr. Eric Middlemost (personal communication, 1982) suggested that the removal of a phase such as kaersutite, or possibly melilite, some species of which contain both $\mathrm{Na}$ and $\mathrm{K}$, from the 
Fig. 4. The $\mathrm{KAlSiO}_{4}-\mathrm{Mg}_{2} \mathrm{SiO}_{4}-\mathrm{SiO}_{2}$ system for $P_{\mathrm{H}_{2}} \mathrm{O}=3 \mathrm{kbar}$, modified from Luth (1967, p. 397, Fig. 6f) and Modreski and Boettcher (1973). Dashed line is a construction line to show position of maximum temperature on the phlogopite (Phlog)-forsterite (Fo) boundary curve. $P$ is beginning-of-melting point for the assemblage Fo + En + Phlog. Star is projection of one possible composition illustrating same of the major phases in the assemblage of the assumed parental material. En, enstatite; Ks, kalsilite; Lc,

leucite; Qz, quartz; Sa, sanidine.

magma may be significant in maintaining a linear relationship between $\mathrm{Na}_{2} \mathrm{O}$ and $\mathrm{K}_{2} \mathrm{O}$. The amphibole has a restricted stability range, and in view of its limited content of alkalies, partitioning into the liquid would of necessity be substantial. Kaersutite is Ne and Lc normative. An amphibole such as potassic richterite, observed in some nodules, has been shown to be unstable in the presence of garnet and aluminous pyroxenes (Kushiro and Erlank 1970, p. 233), and would not be expected in the parental materials now believed to be the principal source of basaltic magmas.

The presence of $\mathrm{H}_{2} \mathrm{O}$, required for the formation of phlogopite or amphibole, results in partial melts that are Qz normative (Modreski and Boettcher 1973). That is, alkali enrichment in the initial liquids would be possible in the presence of those phases, but only subalkaline magmas would be formed. On the other hand, generation of silica-undersaturated melts may result from the presence of $\mathrm{CO}_{2}$ (Kushiro 1968, p. 625, Fig.
4; Eggler 1978). For this reason, potassiumbearing carbonates may be a possible buffer. Unfortunately, $\mathrm{CO}_{2}$ tends to destroy the critical assemblage of olivine and clinopyroxene in the mantle. According to Wyllie and Huang (1975) and Eggler (1975), the reaction $\mathrm{Fo}+\mathrm{Di}+$ $\mathrm{CO}_{2} \rightarrow \mathrm{En}+$ Dol takes place. If excess $\mathrm{CO}_{2}$ is available, the parental assemblage then becomes olivine + orthopyroxene + garnet + dolomite . Dolomite has been searched for in nodules and appears to be absent. The two known inclusions of dolomite in diamonds are believed to be secondary. It thus seems unlikely that a potassium-bearing carbonate serves as a buffer in the generation of alkaline magmas.

\section{Phase equilibria}

Other potential buffers for potassium include nepheline and kalsilite. Both are stable to high pressures, yet neither has been found in nodules. The Buerger composition for nepheline solid 


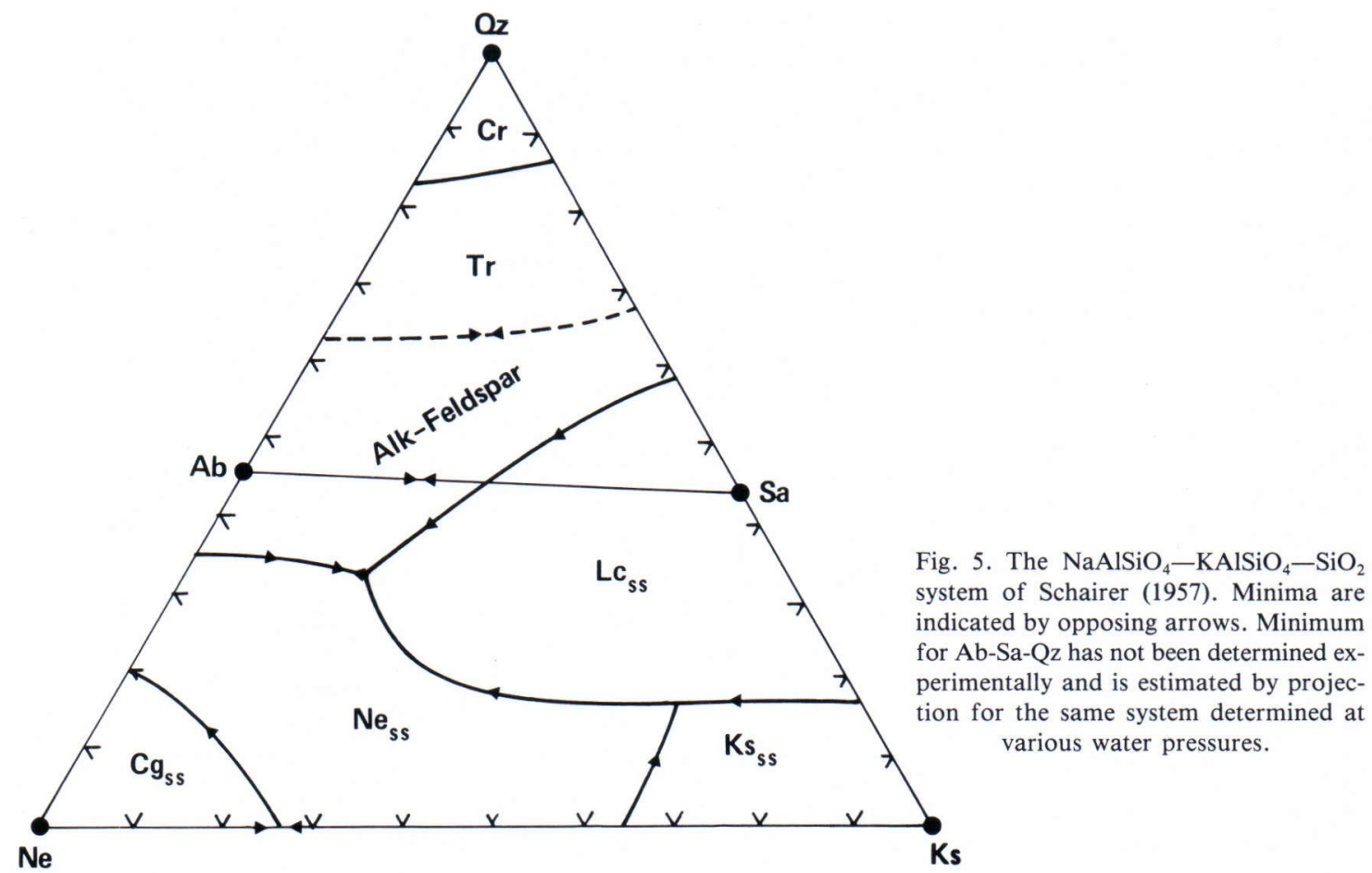

Weight percent

solution contains $1 \mathrm{~K}$ for every $3 \mathrm{Na}$. This particular ratio, characteristic of plutonic rocks, is also close to the minimum melting compositions in Ne-Ks at 73 wt. $\% \mathrm{Ne}$ and in $\mathrm{Ab}-\mathrm{Sa}$ at $65 \mathrm{wt}$. $\% \mathrm{Ab}$ (Fig. 5), and appears to hold irrespective of the silica content. It is noteworthy that $\mathrm{Na}_{2} \mathrm{O}$ and $\mathrm{K}_{2} \mathrm{O}$ are the only major oxides positively correlated with $\mathrm{SiO}_{2}$ in multicomponent associations. The minima of rhyolites, trachytes, and nepheline trachytes in the nepheline-kalsilitequartz system all have roughly the same ratio of $\mathrm{Na}_{2} \mathrm{O}$ and $\mathrm{K}_{2} \mathrm{O}$. The relationship of $\mathrm{Na}_{2} \mathrm{O}$ to $\mathrm{K}_{2} \mathrm{O}$ in the alkali basalts may, therefore, merely reflect persistence at high pressure of the minimum melting relations in the simple systems.

The shifts of the Fo-En boundary curve and the beginning-of-melting point for the initial assemblages $\mathrm{Fo}+\mathrm{En}+\mathrm{Ab}$ and $\mathrm{Fo}+\mathrm{En}+\mathrm{Sa}$ are displayed, respectively, in Figs. 6A and 6B. It appears that, in general, the relative proportion of alkalies in the initial liquids generated from an appropriate mantle assemblage might be preserved until the pressure is reached at which jadeite becomes stable. At that pressure the initial liquid becomes picritic and, more importantly, poorer in $\mathrm{Na}$. Experimental investigation of the relevant beginning-of-melting point in the $\mathrm{Ne}-$ $\mathrm{Ks}-\mathrm{Fo}-\mathrm{Qz}$ system at high pressures will be required to ascertain quantitatively the variation of alkalies in the initial liquids with depth. It is worth emphasizing again that the shift of normative character of the initial melts from $\mathrm{Qz}$ to $\mathrm{Hy}$ to $\mathrm{Ne}$, displayed in Figs. 6A and 6B, is a pressure effect and is not dependent on the degree of melting, although in discussions of the generation of magmas the latter concept is often said to account for it. The continuous nature of the change in invariant points with pressure is compatible with the observed continuum in alkali content between alkali basalt and tholeiite compositions. The alkali basalts appear to be much more abundant in Cenozoic and very late Paleo- 
Fig. 6A. The system $\mathrm{Mg}_{2} \mathrm{SiO}_{4}-\mathrm{NaAlSiO}_{4}-$ $\mathrm{SiO}_{2}$ illustrating the shift of the principal boundary curve between enstatite solid solution $\left(\mathrm{En}_{\mathrm{ss}}\right)$ and forsterite $(\mathrm{Fo})$ as a function of pressure. Completed from isobaric phase diagrams constructed from the data of Schairer and Yoder (1961), Yoder (1964), Kushiro (1968), and Windom and Boettcher (1981). Jd, jadeite; Ab, albite.

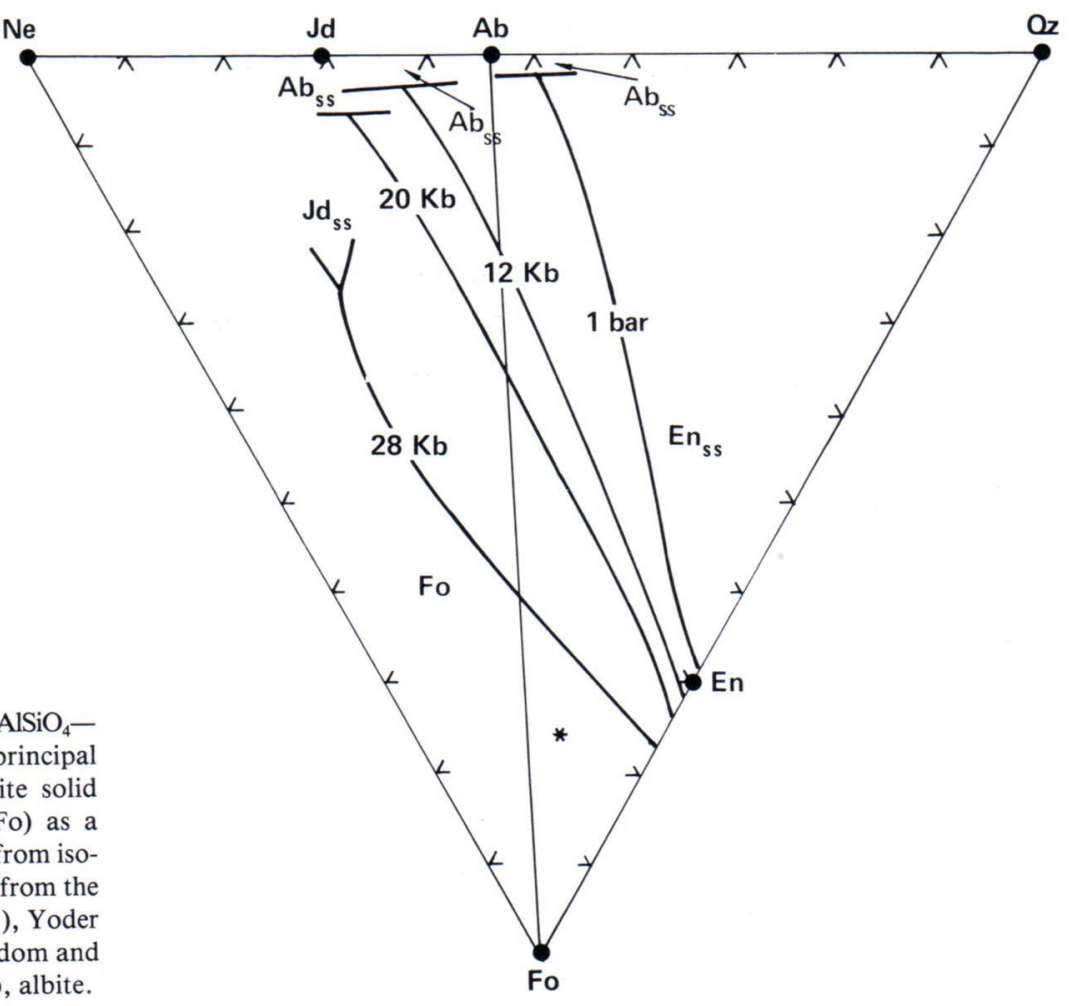

Fig. 6B. The system $\mathrm{Mg}_{2} \mathrm{SiO}_{4}-\mathrm{KAlSiO}_{4}-$ $\mathrm{SiO}_{2}$ illustrating the shift of the principal boundary curve between enstatite solid solution $\left(\mathrm{En}_{\mathrm{ss}}\right)$ and forsterite (Fo) as a function of pressure. Compiled from isobaric phase diagrams constructed from the data of Schairer (1954, p. 506), Schairer and Bowen (1955), Lindsley (1966), Luth (1967), and Wendlandt and Eggler (1980a, b).

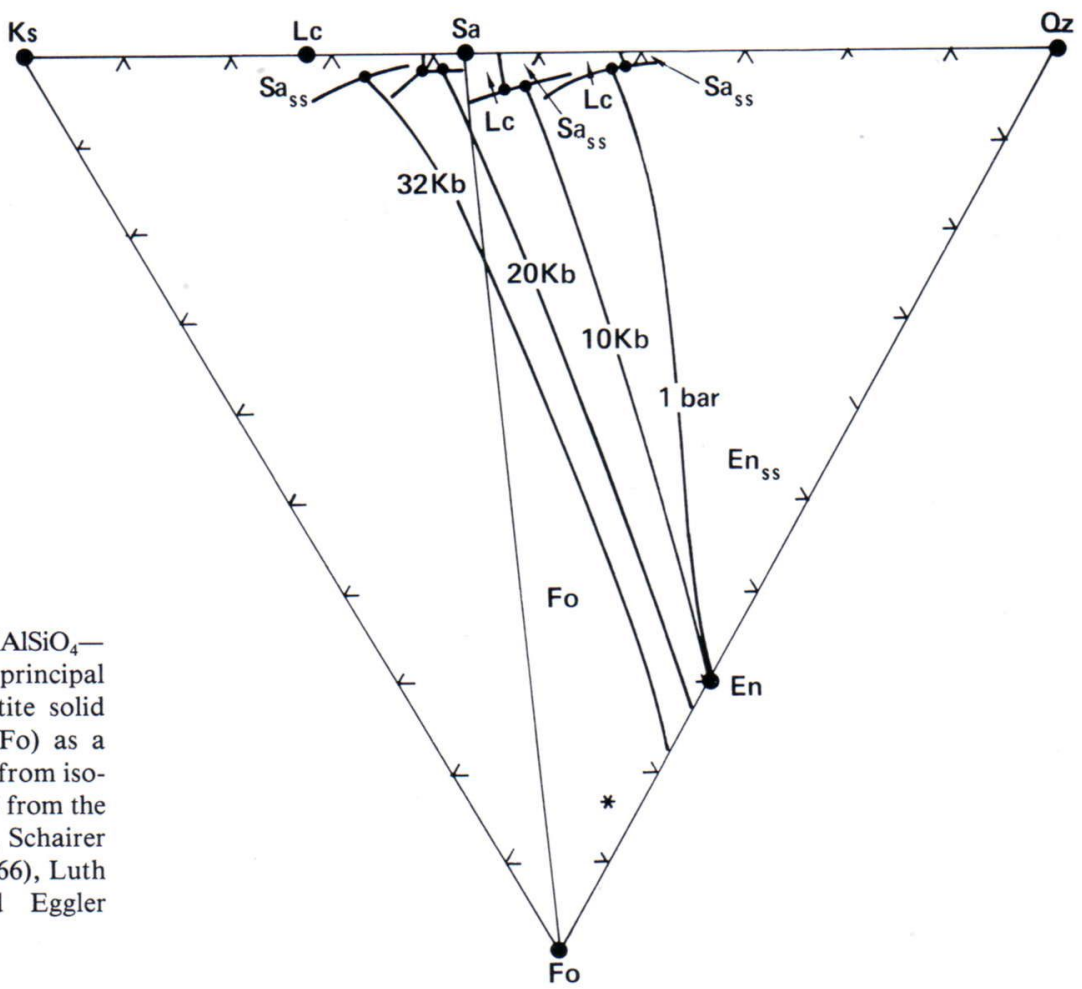


zoic volcanic assemblages than in those of early through mid-Paleozoic age (Poldevaart 1962). If the production of alkali-rich melt fractions is enhanced by high pressures, then it would appear that some sources of younger basaltic magma are quite deep seated.

\section{Metasomatism}

The preferential partitioning of alkalies into the gas phase may also account for the correlation of $\mathrm{K}_{2} \mathrm{O}$ and $\mathrm{Na}_{2} \mathrm{O}$ in magmas. Although the partitioning coefficients between crystal, liquid, and gas in alkaline magmas are not known, Mysen (1981, pp. 347-349; personal communication, 1982) has suggested, on the basis of the enrichment of light rare earths, that at high temperatures the gas phase is enriched in $\mathrm{K}$ relative to $\mathrm{Na}$ with increasing pressure. Metasomatism, therefore, might lead to the more exotic varieties of potassium-rich rocks but not necessarily to alkali basalt. Furthermore, Wendlandt and Eggler (1980a, p. 409) noted that in the Lcnor native rocks there is little correlation between $\mathrm{K}_{2} \mathrm{O}$ and $\mathrm{Na}_{2} \mathrm{O}$, as might be anticipated in a metasomatic process dependent on highly variable parameters such as permeability and porosity. Metasomatic processes, therefore, probably would not result in products with the observed correlation between alkalies.

\section{Trace element behavior}

A strong correlation of $\mathrm{Na}$ and $\mathrm{K}$ may result if they are essentially incompatible elements during the partial melting of the parental material. On the assumption that both almost completely partition into the liquid, the correlation of these elements is fixed primarily by their ratio in the parental material ( $c f$. Frey et al. 1980). Continuous invariant melting where the liquid remains in equilibrium with the parental phases would merely result in dilution. If a magma were removed from the batch, it would retain the initial ratio with a concentration dependent on the stage of dilution. With extreme incompati- bility, fractional melting - that is, continuous separation of liquid from the parental phases would yield only one alkali-enriched magma; subsequent magmas would be essentially devoid of alkalies. Such a partial melting process would not yield a series of alkaline magmas.

The positive intercepts for $\mathrm{Na}_{2} \mathrm{O}$ in the $\mathrm{Na}_{2} \mathrm{O}-\mathrm{K}_{2} \mathrm{O}$ regressions indicate that $\mathrm{Na}$ is less incompatible than $\mathrm{K}$. As $\mathrm{K}$ tends toward zero, apparently one or more phases persist for which the partitioning of $\mathrm{Na}$ into the liquid is of a value such that some $\mathrm{Na}$ is retained in the parental material. It is interesting to note that the volatilefree compositions of chondritic meteorites also reflect the same constraints, both oxides tending toward zero only after $\mathrm{Na}_{2} \mathrm{O}$ drops below $\sim 1$ wt. $\%$ and $\mathrm{K}_{2} \mathrm{O}$, below $\sim 0.1$ wt. $\%$ (Haramura et al. 1983, p. 115).

The similarity of the intercepts for the Hawaiian and Canary Island data suggests that the alkali compositions of the source regions of the two areas are similar. The dissimilarity of the slopes indicates that the parental assemblages, the proportions of phases, or the partitioning coefficients are different as a consequence of differing conditions of magma separation. The near coincidence of slope and intercept for the Hawaiian alkaline and tholeiitic rocks, however, presents a dilemma. The implication is that the sources are similar, the parental assemblages are the same, and the effective partitioning coefficients are essentially the same - even though there are many reasons to believe that the two magma series were generated as a result of major differences in one or all of the cited circumstances. Those differences may be sufficiently subtle at the site of generation to be obscured by the relatively lower correlations of alkalies of the Hawaiian tholeiitic rocks. Other petrographic provinces yielding adequate analytical data with high correlations for both rock series may provide resolution of this dilemma. On the other hand, the proposed hypothesis wherein the alkalies are assigned the role of a trace element may not be applicable. 


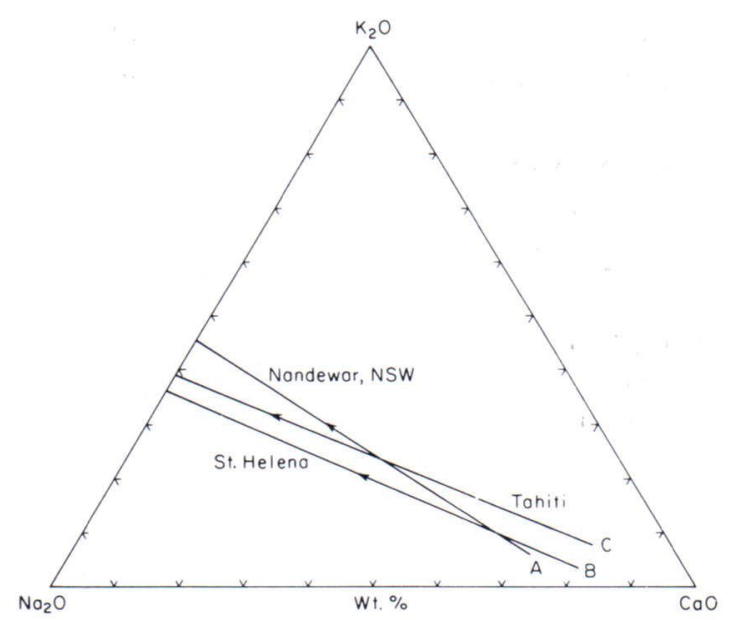

Fig. 7. Trend of $\mathrm{Na}_{2} \mathrm{O}, \mathrm{K}_{2} \mathrm{O}$, and $\mathrm{CaO}$ content of rocks from Nandewar, New South Wales (Abbott 1969, p. 130); St. Helena Island, South Atlantic (Baker 1969); and Tahiti (McBirney and Aoki 1968, p. 545). The arrows indicate the direction of liquid fractionation on the basis of iron enrichment, if that process were applicable. The ends of the lines are representative of compositions of magmas required for mixing, if that process were applicable.

\section{Magma mixing}

A linear relationship between elements has led many investigators to conclude that some magmas are derived by the periodic or continuous mixing of two separate magmas. The strong linear component of variation of $\mathrm{CaO}$ in the ternary $\mathrm{CaO}-\mathrm{Na}_{2} \mathrm{O}-\mathrm{K}_{2} \mathrm{O}$ illustrated in Fig. 7 is a feature common to other oceanic island rock series and applies as well to some continental calcalkaline sequences. Fractional melting of the type described above, in which the alkalies behave as incompatible trace elements, for example, may yield an early magma highly enriched in alkalies that could then after separation mix in various proportions with a subsequent batch melt produced at the same invariant point, or with a magma from an independent source. The volume relations would not necessarily be appropriate, but the concept appears to account for a linear correlation of incompatible elements. It remains to be demonstrated, however, that the alkalies are indeed incompatible elements. The linear cor- relation seems all the more remarkable in the light of the many variables that may influence the mixing of magmas after they leave the site of generation (see, e.g., O'Hara 1977; O'Hara and Mathews 1981).

\section{Closure correlation}

It has been shown (Chayes 1982, p. 245; see also Chayes and Kruskal 1966, p. 700; Chayes 1971, pp. 39-40) that there may be strong positive correlation between any pair of trace elements, or other variables of small initial variance, in successive melt fractions even if these elements are uncorrelated with each other in the parental material. The correlation results because the partial melting imposes new closure conditions - a new set of means and variances - on the melt fraction. It is even possible that pairs of trace elements characterized by a strong negative correlation in the source may be strongly positively correlated in melt fractions. Chayes emphasizes that strong positive correlations are to be expected among trace elements and may convey little or no information about covariances between these variables in the parent. The argument fails if successive magmas are formed strictly at an invariant point; if the melts vary in major element composition, however, the positive covariances between trace elements may be merely the numerical consequence of the closure inherent in the process by which the magma is separated from its parent. On these grounds the strong correlation between $\mathrm{K}_{2} \mathrm{O}$ and $\mathrm{Na}_{2} \mathrm{O}$ may be a direct result of magma separation.

\section{Summary}

The slope of $\mathrm{Na}_{2} \mathrm{O}$ vs. $\mathrm{K}_{2} \mathrm{O}$ appears to be relatively constant in basalts from the Hawaiian Islands and the Canary Islands. This relationship in basic alkaline magmas may result from one, or a combination, of the following factors:

1) buffering by appropriate $\mathrm{Na}$ - and K-bearing phases in the parental material; 
2) phase relations governing the proportion of $\mathrm{Na-}$ and K-bearing phase(s) stable in basic alkaline magma;

3) behavior of $\mathrm{Na}$ and $\mathrm{K}$ as strongly incompatible elements,

4) magma mixing from a common or independent source, or

5) positive correlation imposed by the new closure attending partial melting and magma separation.

Such a regular relationship is not believed to result from the addition or subtraction of materials in a metasomatic process. At this time, there does not appear to be an unambiguous common solution to the alkali-ratio problem; however, one or some combination of several solutions may apply to a particular petrological province.

Acknowledgments. The authors are appreciative of the reviews of the manuscript by Drs. F. R. Boyd, T. N. Irvine, E. Middlemost, Bjørn O. Mysen, and J. F. G. Wilkinson.

\section{References}

Abbott, M. J., 1969. Petrology of the Nandewar volcano, N.S.W., Australia. Contrib. Mineral. Petrol. 20, $115-134$.

Bailey, D. K., 1966. Carbonatite volcanoes and shallow intrusions in Zambia. In: Tuttle, O. F. and Gittins, J. (Editors) Carbonatites. John Wiley \& Sons, New York. $127-154$.

,- 1970 . Volatile flux, heat focusing and the generation of magma. Geol. J. Spec. Issue 2, 177-186.

-, 1974. Nephelinites and ijolites. In: Sørensen, H. (Editor) Alkaline Rocks. John Wiley \& Sons, New York. 53-66.

- \& Schairer, J. F., 1966. The system $\mathrm{Na}_{2} \mathrm{O}-\mathrm{Al}_{2} \mathrm{O}_{3}-$ $\mathrm{Fe}_{2} \mathrm{O}_{3}-\mathrm{SiO}_{2}$ at $1 \mathrm{~atm}$ and the petrogenesis of alkaline rocks. J. Petrol. 7, 114-170.

Baker, I., 1969. Petrology of the volcanic rocks of Saint Helena Island, South Atlantic. Geol. Soc. Am. Bull. 80, 1283-1310.

Barth, T. F. W., 1936. The crystallization process of basalt. Am. J. Sci., 5th Ser., 31, 321-351.

Becke, F., 1903. Die Eruptivgebiete des böhmischen Mittelgebirges und der amerikanischen Andes. Tschermak's Mineral. Petrogr. Mitt., Neue Folge, 22, 209-265.

Bowen, N. L., 1915. The later stages of the evolution of the igneous rocks. J. Geol. Suppl. 23, 1-91.

-, 1928. The Evolution of the Igneous Rocks. Princeton University Press, Princeton, New Jersey. 332 pp.

Brey, G. \& Green, D. H., 1975. The role of $\mathrm{CO}_{2}$ in the genesis of olivine melilitite. Contrib. Mineral. Petrol. 49, 93-103.

Bultitude, R. J. \& Green, D. H., 1968. Experimental studies at high pressures on the origin of olivine nephelinite and olivine-melilite nephelinite magma. Earth Planet. Sci. Lett. 3, 325-337.

Chayes, F., 1971. Ratio Correlation. University of Chicago Press, Chicago. 99 pp.

,- 1982. A possible nonpetrogenetic explanation of positive correlations between trace elements (Open File Report). Carnegie Inst. Washington Year Book 81, 245.

- \& Kruskal, W., 1966. An approximate statistical test for correlations between proportions. J. Geol. 74, 692-702.

-; McCammon, C.; Trochimczyk, J. \& Velde, D., 1977. Rock information system RKNFSYS. Carnegie Inst. Washington Year Book 76, 635-637.

Chinner, G. A. \& Schairer, J. F., 1962. The join $\mathrm{Ca}_{3} \mathrm{Al}_{2} \mathrm{Si}_{3} \mathrm{O}_{12}-$ $\mathrm{Mg}_{3} \mathrm{Al}_{2} \mathrm{Si}_{3} \mathrm{O}_{12}$ and its bearing on the system $\mathrm{CaO}-$ $\mathrm{MgO}-\mathrm{Al}_{2} \mathrm{O}_{3}-\mathrm{SiO}_{2}$ at atmospheric pressure. Am. J. Sci. $260,611-634$.

Daly, R. A., 1910. Origin of alkaline rocks. Geol. Soc. Am. Bull. 21, 87-118.

DeLong, S. E. \& Hoffman, M. A., 1975. Alkali/silica distinction between Hawaiian tholeiites and alkali basalts. Geol. Soc. Am. Bull. 86, 1101-1108.

Eckermann, H. von, 1942. Ett preliminärt meddelande om nya forskningsrön inom Alnö alkalina område. Geol. Fören. Förh. 64, 399-415.

-, 1948. The alkaline district of Alnö Island. Sver. Geol. Unders., Ser. Ca. 36, 1-176.

Eggler, D. H., 1974. Effect of $\mathrm{CO}_{2}$ on the melting of peridotite. Carnegie Inst. Washington Year Book 73, 215-224.

,- 1975 . Peridotite-carbonate relations in the system $\mathrm{CaO}-$ $\mathrm{MgO}-\mathrm{SiO}_{2}-\mathrm{CO}_{2}$. Carnegie Inst. Washington Year Book 74, 468-474.

- , 1978. The effect of $\mathrm{CO}_{2}$ upon partial melting of peridotite in the system $\mathrm{Na}_{2} \mathrm{O}-\mathrm{CaO}-\mathrm{Al}_{2} \mathrm{O}_{3}-\mathrm{MgO}-\mathrm{SiO}_{2}-$ $\mathrm{CO}_{2}$ to $35 \mathrm{~kb}$, with an analysis of melting in a peridotite $-\mathrm{H}_{2} \mathrm{O}-\mathrm{CO}_{2}$ system. An. J. Sci. 278, 305343.

Frey, F. A.; Roden, M. F. \& Zindler, A., 1980. Constraints in mantle source compositions imposed by phosphorus and the rare-earth elements. Contrib. Mineral. Petrol. 75, $165-173$. 
Geijer, P., 1922. Problems suggested by the igneous rocks of the Jotnian and sub-Jotnian age. Geol. Fören. Förh. 44, 438-439.

Goldschmidt, V. M., 1922. Stammestypen der Eruptivgesteine. Videnskap. Skrifter. I. Mat.-Naturv. Klasse, No. 10, Kritiania, 1-12.

Gummer, W. K. \& Burr, S. V., 1943. The nephelinized paragneisses of the Bancroft Region, Ontario (abstract). Science 47, 286.

Hall, A. E. \& Smith, C. B., 1984. Lamproite diamonds Are they different? In: Kimberlite Occurrence and Origin. Department of Geology, University of Western Australia. $21-22$.

Hamilton, $W ., 1965$. Diabase sheets of the Taylor Glacier region, Victoria Land, Antarctica. U.S. Geol. Surv. Prof. Pap. 456-B, 1-71.

Haramura, H.; Kushiro, I. \& Yanai, K. 1983. Chemical compositions of Antarctic meteorites I. Proc. Eighth Symposium on Antarctic Meteorites, ed. T. Nagata. Special Issue No. 30, 109-121.

Harker, A., 1909. The Natural History of the Igneous Rocks. Methuen \& Co., London. 384 pp.

,- 1912 . Some aspects of modern petrology. Pres. Address, Sect. C, Rept. British Assoc. for 1911. 370-381.

Harris, P. G., 1957. Zone refining and the origin of potassic basalts. Geochim. Cosmochim. Acta 12, 195-208.

Holgate, N., 1954. The role of liquid immiscibility in igneous petrogenesis. J. Geol. 62, 439-480.

Holmes, A. \& Harwood, H. F., 1932. Petrology of the volcanic fields east and southeast of Ruwenzori, Uganda. Q. J. Geol. Soc. London 88, 370-442.

-, 1937. The volcanic area of Bufumbira. Geol. Surv. Uganda Mem. No. III, Government Printer, Entebbe. 291 pp.

Iddings, J. P., 1898. On rock classification. J. Geol. 6, 92-111.

Kogarko, L. N.; Ryabchikov, I. D. \& Sørensen, H., 1974. Liquid fractionation. In: Sørensen, H. (Editor) Alkaline Rocks. John Wiley \& Sons, New York. 488-500.

Kushiro, I., 1965. Coexistence of nepheline and enstatite at high pressures. Carnegie Inst. Washington Year Book 64, 109-112.

—, 1968. Compositions of magmas formed by partial zone melting of the earth's upper mantle. J. Geophys. Res. 73, 619-634.

- \& Erlank, A. J., 1970. Stability of potassic richterite. Carnegie Inst. Washington Year Book 68, 231-233.

- \& Kuno, H., 1963. Origin of primary basalt magmas and classification of basaltic rocks. J. Petrol. 4, 75-89.

Larsen, E. S., 1940. Petrographic province of central Montana. Geol. Soc. Am. Bull. 51, 887-948.

Lindsley, D. H., 1966. Melting relations of $\mathrm{KAlSi}_{3} \mathrm{O}_{8}$ : effect of pressures up to 40 kilobars. Am. Mineral. 51, 17931799.

Luth, W. C., 1967. Studies in the system $\mathrm{KAlSiO}_{4}-$
$\mathrm{Mg}_{2} \mathrm{SiO}_{4}-\mathrm{SiO}_{2}-\mathrm{H}_{2} \mathrm{O}: \mathrm{I}$, Inferred phase relations and petrologic applications. J. Petrol. 8, 372-416.

Macdonald, G. A., 1968. Composition and origin of Hawaiian magmas. Geol. Soc. Am. Mem. 116, 477-522.

— \& Katsura, T., 1964. Chemical composition of Hawaiian lavas. J. Petrol. 5, 82-133.

Marshall P., 1914. The sequence of lavas at North Head, Otago. Q. J. Geol. Soc. London 70, 382-406.

McBirney, A. R. \& Aoki, K., 1968. Petrology of the Island of Tahiti. Geol. Soc. Am. Mem. 116, 523-556.

Modreski, P. J. \& Boettcher, A. L., 1973. Phase relationships of phlogopite in the system $\mathrm{K}_{2} \mathrm{O}-\mathrm{MgO}-\mathrm{CaO}-$ $\mathrm{Al}_{2} \mathrm{O}_{3}-\mathrm{SiO}_{2}-\mathrm{H}_{2} \mathrm{O}$ to 35 kilobars: a better model for micas in the interior of the earth. Am. J. Sci. 273, $385-414$.

Mysen, B. O., 1981. Rare earth element partitioning between minerals and $\left(\mathrm{CO}_{2}+\mathrm{H}_{2} \mathrm{O}\right)$ vapor as a function of pressure, temperature, and vapor composition. Carnegie Inst. Washington Year Book 80, 347-349.

— \& Boettcher, A. L., 1975. Melting of a hydrous mantle. II. Geochemistry of crystals and liquids formed by anatexis of mantle peridotite as a function of controlled activities of water, hydrogen, and carbon dioxide. J. Petrol. 16, 549-590.

Nixon, P. H., 1960. A mineralogical and geochemical study of kimberlites and the associated xenoliths. Unpublished Ph.D. thesis, University of Leeds.

O'Hara, M. J., 1977. Geochemical evolution during fractional crystallization of a periodically refilled magma chamber. Nature, London, 266, 503-507.

- \& Mathews, R. E., 1981. Geochemical evolution in an advancing, periodically replenished, periodically topped, continuously fractionated magma chamber. J. Geol. Soc. London 138, 237-277.

- \& Yoder, H. S., Jr., 1967. Formation and fractionation of basic magmas at high pressures. Scottish J. Geol. 3, 67-117.

Poldervaart, A., 1962. Aspects of basalt petrology. J. Geol. Soc. India 3, 1-14.

Powers, H. A., 1935. Differentiation of Hawaiian lavas. Am. J. Sci., 5th Ser., 30, 57-71.

Schairer, J. F., 1954. The system $\mathrm{K}_{2} \mathrm{O}-\mathrm{MgO}-\mathrm{Al}_{2} \mathrm{O}_{3}-\mathrm{SiO}_{2}$. I. Results of quenching experiments on four joins in the tetrahedron cordierite-leucite-silica and on the join cordierite-mullite-potash feldspar. J. Am. Ceram. Soc. 37, 501-533.

-, 1957. Melting relations of the common rock-forming oxides. J. Am. Ceram. Soc. 40, 215-235.

- \& Bowen, N. L., 1955. The system $\mathrm{K}_{2} \mathrm{O}-\mathrm{Al}_{2} \mathrm{O}_{3}-\mathrm{SiO}_{2}$. Am. J. Sci. 253, 681-746.

— \& Yoder, H. S., Jr., 1961. Crystallization in the system nepheline-forsterite-silica at one atmosphere pressure. Carnegie Inst. Washington Year Book 60, 141-144.

— \& Yoder, H. S., Jr., 1964. Crystal and liquid trends in 
simplified alkali basalts. Carnegie Inst. Washington Year Book 63, 65-74.

Seki, Y. \& Kennedy, G. C., 1964. The breakdown of potassium feldspar, $\mathrm{KAlSi}_{3} \mathrm{O}_{8}$, at high temperatures and high pressures. Am. Min. 49, 1688-1706.

Shand, S. J., 1922. The problem of the alkaline rocks. Proc. Geol. Soc. S. Africa 25, xix-xxxiii.

Smyth, C. H., 1913. Composition of the alkaline rocks and its significance as to their origin. Am. J. Sci. 36, 1-36.

,- 1927 . The genesis of alkaline rocks. Proc. Am. Phil. Soc. $66,535-580$.

Tilley, C. E., 1952. Nepheline parageneses. In: Sir Douglas Mawson Anniversary Volume, University of Adelaide. Hassell, Press, Adelaide. 167-177.

- , 1958. Problems of alkali rock genesis. Q. J. Geol. Soc. London 113, 323-360.

- \& Harwood, H. F., 1931. The dolerite-chalk contact of Scawt Hill, Co. Antrim. The production of basic alkali rocks by the assimilation of limestone by basaltic magma. Min. Mag. 22, 439-468.

- \& Thompson, R. N., 1972. Melting relations of some ultra alkali volcanics. Geol. J. 8, 65-70.

-, Yoder, H. S., Jr. \& Schairer, J. F., 1965. Melting relations of volcanic tholeiite and alkali rock series. Carnegie Inst. Washington Year Book 64, 69-82.

Waters, A. C., 1955. Volcanic rocks and the tectonic cycle. Geol. Soc. Am. Spec. Pap. 62, 703-722.

Wendlandt, R. F. \& Eggler, D. H., 1980a. The origins of potassic magmas: 1. Melting relations in the systems $\mathrm{KAlSiO}_{4}-\mathrm{Mg}_{2} \mathrm{SiO}_{4}-\mathrm{SiO}_{2}$ and $\mathrm{KAlSiO}_{4}-\mathrm{MgO}-\mathrm{SiO}_{2}-$ $\mathrm{CO}_{2}$ to 30 kilobars. Am. J. Sci. 280, 385-420.

— \& Eggler, D. H., 1980b. The origins of potassic magmas: 2. Stability of phlogopite in natural spinel lherzolite and in the system $\mathrm{KAlSiO}_{4}-\mathrm{MgO}-\mathrm{SiO}_{2}-\mathrm{H}_{2} \mathrm{O}-\mathrm{CO}_{2}$ at high pressures and high temperatures. Am. J. Sci. 280, $421-458$.

Windom, K. E. \& Boettcher, A. L., 1981. Phase relations for the joins jadeite-enstatite and jadeite-forsterite at 28 $\mathrm{kb}$ and their bearing on basalt genesis. Am. J. Sci. 281, 335-351.

Wyllie, P. J. \& Huang, W. L., 1975. Peridotite, kimberlite, and carbonatite explained in the system $\mathrm{CaO}-\mathrm{MgO}-$ $\mathrm{SiO}_{2}-\mathrm{CO}_{2}$. Geology 3, 621-62:4.

Yoder, H. S., Jr., 1952. The $\mathrm{MgO}-\mathrm{Al}_{2} \mathrm{O}_{3}-\mathrm{SiO}_{2}-\mathrm{H}_{2} \mathrm{O}$ system and the related metamorphic facies. Am. J. Sci., Bowen Vol., pp. 569-627.

—, 1964. Genesis of principal basalt magmas. Carnegie Inst. Washington Year Book 63, 97--101.

- , 1978. Basic magma generation and aggregation. Bull. Volcanol. 41, 301-316.

— \& Tilley, C. E., 1961. Simple basalt systems. Carnegie Inst. Washington Year Book 60, 106-113.

— \& Tilley, C. E., 1962. Origin of basalt magmas: an experimental study of natural and synthetic rock systems. J. Petrol. 3, 342-532. 